\title{
PENGARUH KINERJA KEUANGAN TERHADAP 63 PERTUMBUHAN LABA PADA PERUSAHAAN SUB SEKTOR FOOD AND BEVERAGE YANG TERDAFTAR DI BURSA EFEK INDONESIA PERIODE TAHUN $2010-2019$
}

\author{
Dini Khoirun Nadia'; Jojok Dwiridotjahjono² \\ Program Studi Administrasi Bisnis FISIP UPN "Veteran" Jawa Timur ${ }^{1,2}$ \\ $\underline{\text { dinichoirunnadia@gmail.com }}^{1}, \underline{\text { dwiridotjajono jojok@upnjatim.ac.id }}^{2}$
}

\begin{abstract}
ABSTRAK
Penelitian ini bertujuan untuk mengetahui dan menganalisis kinerja keuangan yang terdiri dari : current ratio, quick ratio, debt to equity ratio, net profit margin, dan return on equity terhadap pertumbuhan laba pada Perusahaan Sub Sektor Food and Beverage yang terdaftar di Bursa Efek Indonesia periode tahun 2010 - 2019. Jenis penelitian yang digunakan yaitu jenis penelitian deskriptif dengan pendekatan kuantitatif. Populasi dalam penelitian ini adalah seluruh perusahaan sub sektor food and beverage yang terdaftar di Bursa Efek Indonesia periode tahun 2010 - 2019 yaitu sejumlah 30 perusahaan. Teknik penarikan sampel yang digunakan yaitu purposive sampling dan menghasilkan sampel sebanyak 13 perusahaan yang memenuhi persyaratan kriteria. Teknik analisis yang digunakan adalah uji asumsi klasik, regresi linier berganda, uji f, uji $t$, dan koefisien determinasi. Hasil penelitian mengidentifikasi bahwa antara pertumbuhan laba dengan variabel current ratio dan debt to equity ratio secara parsial berpengaruh signifikan terhadap pertumbuhan laba. Sedangkan quick ratio, net profit margin, dan return on equity secara parsial tidak terdapat pengaruh signifikan terhadap pertumbuhan laba. Secara simultan, seluruh variabel memiliki pengaruh signifikan terhadap pertumbuhan laba.
\end{abstract}

Kata Kunci : Pertumbuhan Laba, Current Ratio, Quick Ratio, Debt To Equity Ratio, Net Profit Margin, dan Return On Equity

\section{Abstract}

This study aims to determine and analyze financial performance consisting of: current ratio, quick ratio, debt to equity ratio, net profit margin, and return on equity to profit growth in Food and Beverage Sub-Sector Companies listed on the Indonesia Stock Exchange for the period of the year. 2010 - 2019. The type of research used is descriptive research with a quantitative approach. The population in this study were all food and beverage sub-sector companies listed on the Indonesia Stock Exchange for the period 2010 - 2019, namely 30 companies. The sampling technique used was purposive sampling and produced a sample of 13 companies that met the criteria. The analysis technique used is the classical assumption test, multiple linear regression, $f$ test, $t$ test, and the coefficient of determination. The results of the study identified that the profit growth with the current ratio variable and the partial debt to equity ratio had a significant effect on profit growth. Meanwhile, the quick ratio, net profit margin, 
and return on equity partially do not have a significant effect on profit growth. Simultaneously, all variables have a significant influence on profit growth.

Keywords: Profit Growth, Current Ratio, Quick Ratio, Debt To Equity Ratio, Net Profit Margin, dan Return On Equity

Diterima: 30 Maret 2021; Direvisi: 6 April 2021; Diterbitkan: 20 April 2021

\section{PENDAHULUAN}

Pertumbuhan bisnis dikala ini telah menghadapi kemajuan yang sangat kilat dengan didukung oleh teknologi yang semakin mutahir pula. Perusahaan food and beverage (F\&B) merupakan salah satu bisnis yang sangat menjanjikan karena makanan dan minuman merupakan kebutuhan pokok yang akan selalu dibutuhkan oleh masyarakat. Semakin bertambahnya tahun, industri F\&B mengalami peningkatan yang cukup signifikan seiring dengan bermunculannya produk makanan dan minuman yang mengikuti perkembangan zaman atau trend yang sedang terjadi saat itu. Banyak bermunculannya bisnis-bisnis sejenis menimbulkan persaingan menjadi tajam sehingga para pelaku bisnis wajib mempunyai inspirasi ataupun inovasi agar bisnis yang dibangun sanggup bersaing dengan bisnis-bisnis yang ada.

Selain inovasi, kinerja perusahaan dalam mengelola setiap lini manajemen juga menjadi suatu hal yang harus diperhatikan untuk mencapai tujuan yang ingin dicapai. Kinerja perusahaan dapat dilihat dari sebagaimana perusahaan memanfaatkan sumber daya yang ada semaksimal mungkin. Adapun salah satu parameter penilaian kinerja perusahaan tersebut adalah pertumbuhan laba.

Pertumbuhan laba perusahaan yang baik mencerminkan bahwa kondisi kinerja perusahaan juga baik, jika kondisi ekonomi baik pada umumnya pertumbuhan perusahaan baik. Oleh karena laba merupakan ukuran kinerja dari suatu perusahaan, maka semakin tinggi laba yang dicapai perusahaan, mengindikasikan semakin baik kinerja perusahaan. Dengan demikian para investor tertarik untuk menanamkan modalnya. (Dewi Utari, Ari dan Darsono 2014:67).

Teknik analisis yang digunakan dalam penelitian ini menggunakan analisis rasio keuangan. Menurut Harahap (2015:297), rasio keuangan adalah angka yang diperoleh dari hasil perbandingan dari satu pos laporan keuangan dengan pos lainnya yang mempunyai hubungan yang relevan dan signifikan.

Dalam penelitian ini, rasio yang digunakan yaitu rasio likuiditas diwakili oleh current ratio dan quick ratio, rasio leverage yang diwakili oleh debt to equity ratio, serta rasio profitabilitas diwakili oleh net profit margin dan return on equity.

Berdasarkan latar belakang diatas, maka dapat dirumuskan suatu rumusan masalah sebagai berikut :

1. Apakah kinerja keuangan yang terdiri dari: current ratio, quick ratio, debt to equity ratio, net profit margin, dan return on equity berpengaruh secara simultan terhadap pertumbuhan laba Perusahaan Sub Sektor Food and Beverage yang terdaftar di Bursa Efek Indonesia periode 2010 - 2019 ?

2. Apakah kinerja keuangan yang terdiri dari: current ratio, quick ratio, debt to equity ratio, net profit margin, dan 
return on equity berpengearuh secara parsial terhadap pertumbuhan laba Perusahaan Sub Sektor Food and Beverage yang terdaftar di Bursa Efek Indonesia periode $2010-2019$ ?

\section{LANDASAN TEORI}

\section{Pengertian Manajemen Keuangan}

Menurut I Made Sudana (2015:14), Manajemen keuangan merupakan salah satu bidang fungsional yang mempelajari tentang investasi, pendanaan, dan pengelolaan laba bersih perusahaan, apakah dibayarkan sebagai dividen atau diinvestasikan kembali dalam perusahaan.

\section{Pengertian Laporan Keuangan}

Laporan keuangan adalah sebuah laporan yang diterbitkan oleh perusahaan untuk para pemegang sahamnya. Laporan ini memuat laporan keuangan dasar dan juga analisis manajemen atas operasi tahun lalu dan pendapat mengenai prospek prospek perusahaan dimasa mendatang (Ahmad Rodoni dan Herni Ali, 2014:13).

\section{Pengertian Analisis Laporan Keuangan}

Analisis laporan keuangan menurut Harahap (2015:190) adalah menguraikan pos-pos laporan keuangan (financial statement) menjadi unit informasi yang lebih kecil dan melihat hubungannya yang bersifat signifikan atau yang mempunyai makna antara satu dengan yang lain baik antara data kuantitatif maupun data nonkuantitatif dengan tujuan untuk mengetahui kondisi keuangan lebih dalam yang sangat penting dalam proses menghasilkan keputusan yang tepat.

\section{Pengertian Analisis Rasio Keuangan}

Analisis rasio menurut menurut Harahap (2015: 297), rasio keuangan adalah angka yang diperoleh dari hasil perbandingan dari satu pos laporan keuangan dengan pos lainnya yang mempunyai hubungan yang relevan dan signifikan.

\section{Rasio Keuangan Yang Mempengaruhi Pertumbuhan Laba}

\section{Current Ratio}

Menurut Agnes Sawir (2017:8) current ratio merupakan rasio yang berguna untuk mengetahui kemampuan perusahaan membayar hutang jangka pendek karena rasio ini menunjukkan seberapa jauh tuntutan dari kreditur jangka pendek dipenuhi oleh aktiva yang diperkirakan menjadi uang tunai dalam periode yang sama dengan jatuh tempo utang. Rumus yang digunakan adalah sebagai berikut :

$$
\begin{gathered}
\text { Current Ratio }=\frac{\text { Aktiva Lancar }}{\text { Utang Lancar }} \times 100 \% \\
\text { Pengaruh current ratio terhadap }
\end{gathered}
$$
pertumbuhan laba adalah semakin tinggi nilai current ratio maka laba bersih yang dihasilkan perusahaan semakin rendah, karena rasio lancar tinggi menunjukkan adanya kelebihan aktiva lancar yang tidak baik terhadap profitabilitas perusahaan (Nurvigia, 2010).

\section{Quick Ratio}

Quick ratio menurut Munawir (2010:74) yaitu rasio yang mengukur kemampuan perusahaan dalam memenuhi hutangnya dengan tidak memperhitungkan persediaan. Persediaan tidak digunakan karena memerlukan waktu yang cukup lama untuk dicairkan menjadi uang kas, meskipun pada kenyataannya mungkin persediaan lebih likuid daripada piutang. 
Rumus yang digunakan adalah sebagai berikut :

$$
=\frac{\text { Quick Ratio }}{\text { Aktiva Lancar - Inventory }} \times 100 \%
$$

Kemampuan perusahaan dalam pembayaran hutang lancar dengan aktiva lancar tanpa persediaan akan mempengaruhi pertimbangan calon kreditur dalam pemberian kredit jangka pendek kepada perusahaan. Kredit yang diberikan oleh kreditur dapat memudahkan aktivitas perusahaan, sehingga perusahaan lebih mudah menghasilkan laba (Widhi, 2011).

\section{Debt to Equity Ratio}

Menurut Agus Sartono (2010:217) debt to equity ratio adalah imbangan antara utang yang dimiliki perusahaan dengan modal sendiri. Semakin tinggi rasio ini berarti modal sendiri semakin sedikit dengan utangnya. Rumus yang digunakan adalah sebagai berikut :

Debt to Equity Ratio

$$
=\frac{\text { Total Hutang }}{\text { Modal }} \times 100 \%
$$

Semakin tinggi debt to equity ratio menunjukkan bahwa total hutang yang tinggi dimana banyaknya dana kreditor yang masuk sehingga dapat digunakan untuk menghasilkan atau meningkatkan laba. Dana tersebut dapat digunakan dalam membantu proses produksi yang dapat meningkatkan penjualan atau pendapatan perusahaan (Oktanto dan Nuryatnoo, 2014).

\section{Net Profit Margin}

Menurut Hery (2015:235) net profit margin merupakan rasio yang berguna untuk mengukur besarnya persentasi laba bersih atas penjualan bersih. Adapun rumus untuk mencari net profit margin Kasmir (2018:200) adalah :

$$
\begin{aligned}
& \text { Net Profit Margin } \\
& =\frac{\text { Laba Setelah Pajak }}{\text { Penjualan }} \times 100 \%
\end{aligned}
$$

Tingginya rasio ini akan menyebabkan suatu perusahaan dianggap memiliki kinerja yang baik, selain itu meningkatnya net profit margin juga akan menarik investor untuk menginvestasikan modalnya karena semakin tinggi net profit margin menandakan laba perusahaan tersebut semakin besar.

\section{Return on Equity}

Pengertian Return on Equity
menurut Sartono $(2012: 124)$ yaitu mengukur kemampuan perusahaan memperoleh laba yang tersedia bagi pemegang saham perusahaan. Rumus yang digunakan adalah sebagai berikut :

$$
\begin{aligned}
& \text { Return on Equity } \\
& =\frac{\text { Laba Setelah Pajak }}{\text { Modal }} \times 100 \%
\end{aligned}
$$

Modal yang digunakan secara efektif dan efisien dapat meningkatkan kepercayaan kepada para pemegang saham terkait pembayaran deviden sehingga tidak akan mengganggu perusahaan dalam meningkatkan penjualan untuk meningkatkan laba.

\section{METODE PENELITIAN}

Jenis penelitian yang digunakan yaitu jenis penelitian deskriptif dengan pendekataan kuantitatif. Populasi dalam penelitian ini adalah seluruh perusahaan sub sektor F\&B yang aktif terdaftar di Bursa Efek Indonesia (BEI) yaitu sejumlah 30 perusahaan yang menerbitkan laporan keuangan selama periode penelitian yaitu 2010 - 2019. Dari 30 tersebut, hanya 
diambil 13 perusahaan yang digunakan sebagai sampel penelitian dikarenakan sebagian populasi tidak memenuhi kriteria penentuan atau penarikan sampel. Teknik penarikan sampel yang digunakan adalah "Purposive Sampling" yaitu teknik penarikan sampel bersumber pada kriteria yang didetetapkan. Kriteria - kriteria yang menjadi faktor penentu dalam sampel pada penelitian ini adalah sebagai berikut:

1. Perusahaan sub sektor F\&B yang terdaftar di BEI secara berturut-turut dari tahun 2010 - 2019.

2. Perusahaan sub sektor F\&B yang menerbitkan data - data laporan keuangan secara lengkap dan konsisten mulai periode tahun $2010-2019$.

3. Perusahaan sub sektor F\&B telah terdaftar di BEI tidak mengalami delisting selama periode penelitian.

4. Perusahaan sub sektor F\&B yang telah terdaftar di BEI tidak menghasilkan laba negatif selama periode penelitian

Jenis data yang digunakan dalam penelitian ini adalah data sekunder. Sumber data yang digunakan adalah data sekunder. Data yang digunakan dalam penelitian ini diperoleh dari laporan tahunan yang diterbitkan oleh perusahaan sub sektor F\&B yang terdaftar di BEI pada periode 2010 - 2019.

\section{HASIL PENELITIAN PEMBAHASAN}

DAN

\section{Multikolinieritas}

Tabel 1. Hasil Uji Multikolinieritas

\begin{tabular}{|l|r|r|}
\hline \multirow{2}{*}{ Model } & \multicolumn{2}{|c|}{$\begin{array}{c}\text { Collinearity } \\
\text { Statistics }\end{array}$} \\
\cline { 2 - 3 } $1 \quad$ (Constant) & Tolerance & \multicolumn{1}{c|}{ VIF } \\
\hline & & \\
Curret Ratio & .149 & 6.722 \\
\hline
\end{tabular}

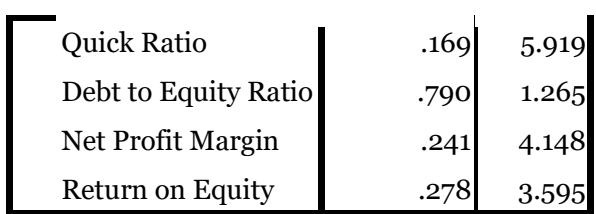

Sumber: Data Diolah Oleh Peneliti

Berdasarkan tabel 1 diatas, menunjukkan bahwa hasil pengujian multikolinieritas untuk variabel $\mathrm{CR}, \mathrm{QR}$, DER, NPM dan ROE memiliki nilai tolerance $>0,10$ dan nilai $\mathrm{VIF}<10$. Maka, dapat disimpulkan bahwa seluruh variabel yang digunakan dalam penelitian ini terbebas dari gejala multikolinieritas.

\section{Autokorelasi}

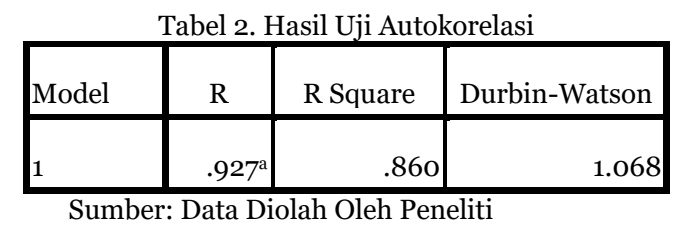

Berdasarkan tabel 2 dapat diketahui bahwa nilai Durbin-Watson sebesar 1.068. Dengan demikian, maka $-2<\mathrm{dw}(1.068)<$ +2 sehingga dapat disimpulkan bahwa dalam penelitian ini tidak terjadi masalah autokorelasi.

\section{Heterokedastisitas}

Scatterplot

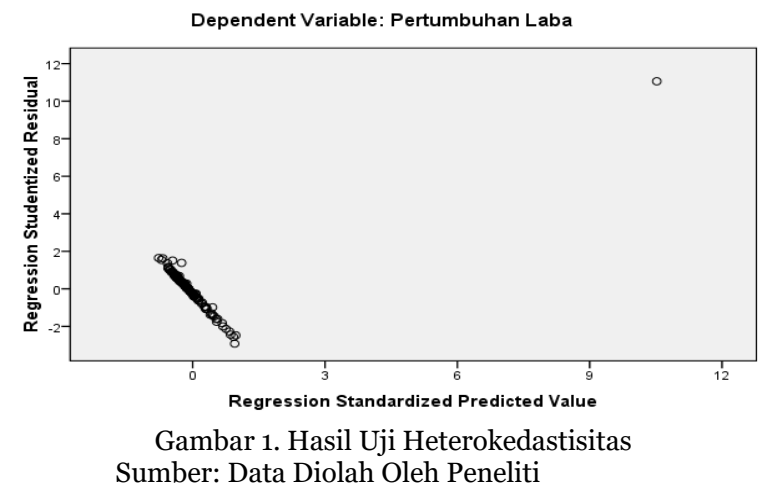


Berdasarkan gambar 1 terlihat titiktitik tidak menyebar secara acak serta membentuk pola tertentu. Hal ini berarti telah terjadi heterokedastitsitas pada model regresi yang akan digunakan dalam pengujian hipotesis. Maka dari itu perlu adanya perbaikan data dengan transformasi logaritma natural (Ln). Setelah dilakukannya transformasi data, maka hasil pengujian kembali untuk data yang bermasalah adalah sebagai berikut :

Tabel 3. Hasil Uji Heterokedastisitas Setelah Transformasi Data

\begin{tabular}{|l|r|}
\hline \multicolumn{1}{|c|}{} & \\
Model & \multicolumn{1}{|c|}{ Sig. } \\
\hline $1 \quad$ (Constant) & .000 \\
$\mathrm{X} 1$ & .865 \\
$\mathrm{X} 2$ & .710 \\
$\mathrm{X} 3$ & .173 \\
$\mathrm{X} 4$ & .678 \\
$\mathrm{X} 5$ & .612 \\
\hline \multicolumn{2}{|c|}{} \\
\hline
\end{tabular}

Sumber: Data Diolah Oleh Peneliti

Berdasarkan tabel 3 dapat dilihat bahwa data telah terdistribusi secara normal. Hal ini ditunjukkan dengan nilai signifikansi dari masing - masing variabel berada diatas $5 \%$ atau 0,05 sehingga dapat disimpulkan bahwa tidak terjadi masalah heterokedastisitas.

\section{Normalitas}

Berdasarkan gambar 2 terlihat titiktitik menyebar disekitar garis diagonal dan mengikuti arah garis diagonal Y. dengan demikian, maka dapat disimpulkan bahwa data yang diperoleh dalam penelitian ini berdistribusi normal.
Normal P-P Plot of Regression Standardized Residual

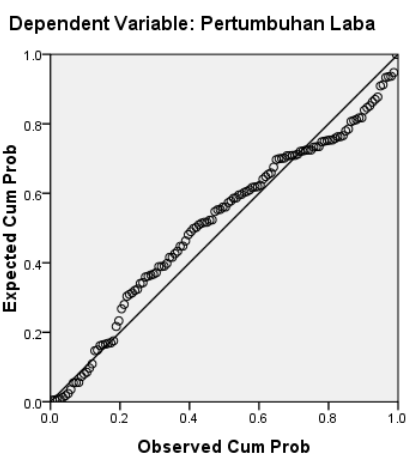

Gambar 2.Hasil Uji Normalitas Sumber: Data Diolah Oleh Peneliti

\section{Analisis Regresi Linier Berganda}

Tabel 4. Hasil Uji Analisis Regresi Linier Berganda

\begin{tabular}{|l|r|r|}
\hline \multirow{2}{*}{} & \multicolumn{2}{|c|}{$\begin{array}{c}\text { Unstandardized } \\
\text { Coefficients }\end{array}$} \\
\cline { 2 - 3 } Model & \multicolumn{1}{|c|}{ B } & Std. Error \\
\hline 1 (Constant) & -2787.314 & 214.245 \\
Curret Ratio & 5.612 & 1.501 \\
Quick Ratio & -.968 & 1.587 \\
$\begin{array}{l}\text { Debt to Equity } \\
\text { Ratio }\end{array}$ & 1932.034 & 74.493 \\
$\begin{array}{l}\text { Net Profit } \\
\text { Margin }\end{array}$ & -16.643 & 21.180 \\
Return on & -1.150 & 6.585 \\
Equity &
\end{tabular}

a. Dependent Variable: Pertumbuhan Laba Sumber: Data Diolah Oleh Peneliti

Berdasarkan tabel 4, diperoleh persamaan regresi linier berganda sebagai berikut :

$\mathrm{PL}=-2787,314+5,612 \mathrm{CR}-0,968 \mathrm{QR}+$ 1932,034DER - 16,643NPM - 1,15OROE

Berdasarkan persamaan regresi linier berganda diatas, dapat ditarik kesimpulan sebagai berikut :

a. Nilai constant

Nilai constant dari persamaan regresi sebesar -2787,314 
b. Current Ratio (CR)

Nilai konstanta regresi untuk variabel Current Ratio (CR) sebesar 5,612 menunjukkan bahwa apabila CR naik 1\%, maka pertumbuhan laba akan mengalami kenaikan sebesar 5,612\% dengan anggapan faktor lain konstan.

c. Quick Ratio (QR)

Nilai konstanta regresi untuk variabel Quick Ratio (QR) sebesar -0,968 menunjukkan bahwa apabila QR naik $1 \%$, maka pertumbuhan laba akan mengalami penurunan sebesar $0,968 \%$ dengan anggapan faktor lain konstan.

d. Debt To Equity Ratio (DER)

Nilai konstanta regresi untuk variabel Debt To Equity Ratio (DER) sebesar 1932,034 menunjukkan bahwa apabila DER naik 1\%, maka pertumbuhan laba akan mengalami kenaikan sebesar 1932,034\% dengan anggapan faktor lain konstan.

e. Net Profit Margin (NPM)

Nilai konstanta regresi untuk variabel Net Profit Margin (NPM) sebesar 16,643 menunjukkan bahwa apabila NPM naik 1\%, maka pertumbuhan laba akan mengalami penurunan sebesar $16,643 \%$ dengan anggapan faktor lain konstan.

f. Return On Equity (ROE)

Nilai konstanta regresi untuk variabel Return On Equity (ROE) sebesar -1,150 menunjukkan bahwa apabila ROE naik $1 \%$, maka pertumbuhan laba akan mengalami penurunan sebesar $1,150 \%$ dengan anggapan faktor lain konstan.

\section{Koefisien Regresi ( $\left.\mathbf{R}^{2}\right)$}

Tabel 5. Hasil Uji Koefisien Determinasi

\begin{tabular}{|l|c|r|c|c|}
\hline Model & \multicolumn{1}{|c|}{$\mathrm{R}$} & R Square & $\begin{array}{c}\text { Adjusted R } \\
\text { Square }\end{array}$ & $\begin{array}{c}\text { Std. Error of the } \\
\text { Estimate }\end{array}$ \\
\hline 1 & $.927^{\mathrm{a}}$ & .860 & .854 & 1052.48676 \\
\hline
\end{tabular}

Berdasarkan tabel 5 diatas, hasil perhitungan R Square menunjukkan nilai o,860. Hal ini menunjukkan bahwa sebesar 86\% pertumbuhan laba dipengaruhi oleh variabel current ratio, quick ratio, debt to equity ratio, net profit margin, dan return on equity sedangkan sebesar $14 \%$ sisanya dipengaruhi oleh faktor - faktor lain yang tidak termasuk dalam penelitian ini.

\section{Uji F}

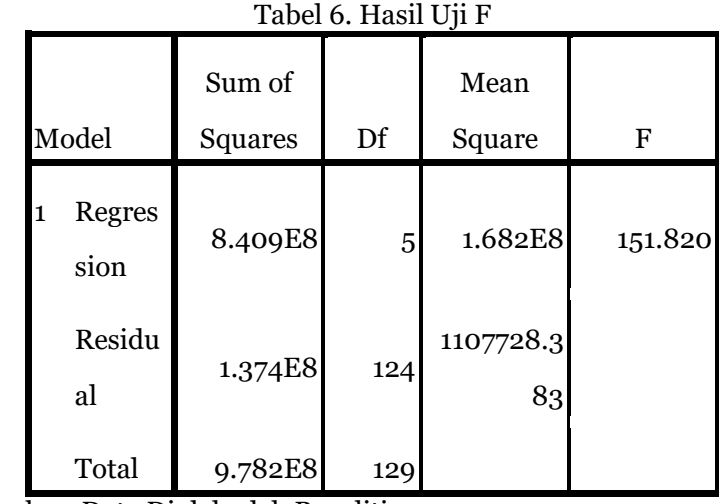

Sumber: Data Diolah oleh Peneliti

Berdasarkan hasil penelitian yang telah dilakukan, diperoleh nilai $\mathrm{F}$ hitung sebesar $151,820>\mathrm{F}$ tabel sebesar 2,29 dengan nilai signifikansi o,ooo yang berarti nilai tersebut lebih kecil dari tingkat nilai signifikansi yang digunakan sebesar 0,05. Hal tersebut menunjukkan bahwa variabel dependen yang terdiri dari Current Ratio, Quick Ratio, Debt To Equity Ratio, Net Profit Margin, dan Return On Equity secara bersama - sama berpengaruh terhadap pertumbuhan laba.

\section{Uji T}

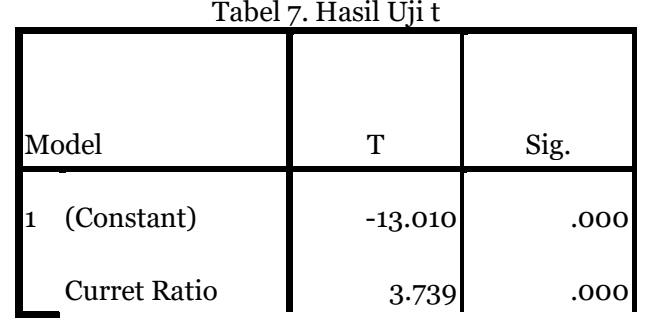




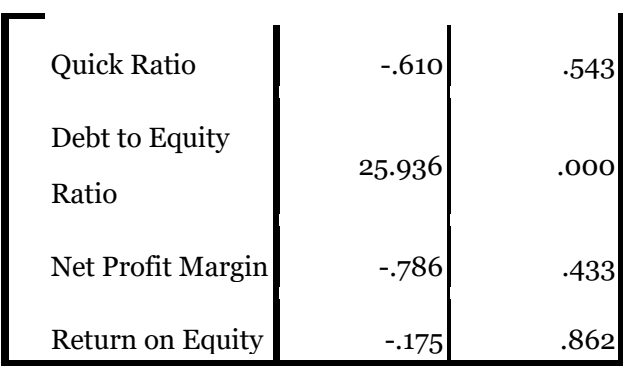

Sumber: Data Diolah oleh Peneliti

Berdasarkan perhitungan yang telah dilakukan, diperoleh hasil uji sebagai berikut :

Uji Parsial untuk Variabel Current Ratio terhadap Pertumbuhan Laba

Berdasarkan hasil penelitian yang telah dilakukan, diperoleh nilai t hitung sebesar 3,74 > t tabel sebesar 1,97 dengan nilai signifikansi 0 ,oo yang berarti nilai tersebut lebih kecil dari tingkat nilai signifikansi yang digunakan yaitu sebesar 0,05. Hal tersebut menunjukkan bahwa Current Ratio berpengaruh signifikan terhadap pertumbuhan laba.

\section{Uji Parsial untuk Variabel Quick Ratio terhadap Pertumbuhan Laba}

Berdasarkan hasil penelitian yang telah dilakukan, diperoleh nilai t hitung sebesar $0,61<\mathrm{t}$ tabel sebesar 1,97 dengan nilai signifikansi 0,54 yang berarti nilai tersebut lebih besar dari tingkat nilai signifikansi yang digunakan sebesar 0,05. Hal tersebut menunjukkan bahwa Quick Ratio tidak berpengaruh signifikan terhadap pertumbuhan laba.

Uji Parsial untuk Variabel Debt to Equity Ratio terhadap Pertumbuhan Laba

Berdasarkan hasil penelitian yang telah dilakukan, diperoleh nilai t hitung sebesar $25,93>t$ tabel sebesar 1,97 dengan nilai signifikansi o,oo yang berarti nilai tersebut lebih besar dari tingkat nilai signifikansi yang digunakan sebesar 0,05. Hal tersebut menunjukkan bahwa Debt to Equity Ratio berpengaruh signifikan terhadap pertumbuhan laba.

\section{Uji Parsial untuk Variabel Net Profit} Margin terhadap Pertumbuhan Laba

Berdasarkan hasil penelitian yang telah dilakukan, diperoleh nilai t hitung sebesar $0,786<t$ tabel sebesar 1,97 dengan nilai signifikansi 0,433 yang berarti nilai tersebut lebih besar dari tingkat nilai signifikansi yang digunakan sebesar 0,05. Hal tersebut menunjukkan bahwa Net Profit Margin tidak berpengaruh signifikan terhadap pertumbuhan laba.

\section{Uji Parsial untuk Variabel Return on Equity terhadap Pertumbuhan Laba}

Berdasarkan hasil penelitian yang telah dilakukan, diperoleh nilai thitung sebesar $0,175<\mathrm{t}$ tabel sebesar 1,97 dengan nilai signifikansi 0,862 yang berarti nilai tersebut lebih besar dari tingkat nilai signifikansi yang digunakan sebesar 0,05. Hal tersebut menunjukkan bahwa Return on Equity tidak berpengaruh signifikan terhadap pertumbuhan laba.

\section{Pembahasan}

\section{Pengaruh Current Ratio terhadap Pertumbuhan Laba}

Berdasarkan hasil penelitian yang telah dilakukan, diperoleh nilai $\mathrm{t}$ hitung sebesar 3,74 > t tabel sebesar 1,97 dengan nilai signifikansi 0,00 yang berarti nilai tersebut lebih kecil dari tingkat nilai signifikansi yang digunakan sebesar 0,05. Hal tersebut menunjukkan bahwa Current Ratio berpengaruh signifikan terhadap pertumbuhan laba. 
Hasil penelitian ini mendukung penelitian yang dilakukan oleh Suyono dan Marina (2020) menyatakan bahwa Current Ratio berpengaruh signifikan terhadap pertumbuhan laba. Sedangkan menurut Ulfinabella Risnawati Aryanto, Kartika Hendra Titisari, dan Siti Nurlaela (2018) yang menyatakan bahwa Current Ratio tidak berpengaruh signifikan terhadap pertumbuhan laba.

\section{Pengaruh Quick Ratio terhadap Pertumbuhan Laba}

Berdasarkan hasil penelitian yang telah dilakukan, diperoleh nilai $\mathrm{t}$ hitung sebesar $-0,61<\mathrm{t}$ tabel sebesar 1,97 dengan nilai signifikansi 0,54 yang berarti nilai tersebut lebih besar dari tingkat nilai signifikansi yang digunakan sebesar 0,05. Hal tersebut menunjukkan bahwa Quick Ratio tidak berpengaruh signifikan terhadap pertumbuhan laba.

Hasil penelitian ini didukung penelitian sebelumnya yang dilakukan oleh Marselia Purnama (2019) yang menunjukkan bahwa Quick Ratio mempunyai pengaruh negatif terhadap pertumbuhan laba, artinya setiap kenaikan Quick Ratio akan diikuti dengan penurunan pertumbuhan laba. Hal ini menunjukkan bahwa Quick Ratio tidak signifikan dalam mempengaruhi pertumbuhan laba perusahaan. Hal ini diprediksi karena kas dan setara kas yang menurun, biaya dibayar dimuka yang sering meningkat jumlahnya, dan piutang yang tidak tertagih sehingga perusahaan tidak mampu membayar utang lancarnya. Hasil yang sama ditunjukkan dengan penelitian yang dilakukan oleh Kharisma Aulia Dianitha, Endang Masitoh, dan Purnama Siddi (2020) yang menyatakan bahwa Quick Ratio tidak berpengaruh terhadap pertumbuhan laba.

\section{Pengaruh Debt to Equity Ratio terhadap Pertumbuhan Laba}

Berdasarkan hasil penelitian yang telah dilakukan, diperoleh nilai $\mathrm{t}$ hitung sebesar 25,94 > t tabel sebesar 1,97 dengan nilai signifikansi 0 ,oo yang berarti nilai tersebut lebih kecil dari tingkat nilai signifikansi yang digunakan sebesar 0,05. Hal tersebut menunjukkan bahwa Debt to Equity Ratio berpengaruh signifikan terhadap pertumbuhan laba.

Hasil penelitian ini tidak didukung penelitian yang dilakukan oleh Ulfinabella Risnawati Aryanto, Kartika Hendra Titisari, dan Siti Nurlaela (2018), Gischanovelia Makiwan (2018), dan Marselia Purnama (2019) yang menunjukkan bahwa Debt to Equity Ratio mempunyai pengaruh negatif terhadap pertumbuhan laba, artinya setiap kenaikan Debt to Equity Ratio akan diikuti dengan penurunan pertumbuhan laba. Hal ini menunjukkan bahwa Debt to Equity Ratio tidak signifikan dalam mempengaruhi pertumbuhan laba perusahaan karena modal yang dimiliki perusahaan lebih kecil dari pada kewajiban perusahaan atau perusahaan lebih banyak menggunakan dana dari pihak luar (utang) untuk modal kerja atau operasional perusahaan. Perusahaan mendapatkan bunga dari utang tersebut dan harus dibayar sehingga perusahaan mengalami penurunan laba atau bahkan mengalami kerugian.

\section{Pengaruh Net Profit Margin terhadap Pertumbuhan Laba}

Berdasarkan hasil penelitian yang telah dilakukan, diperoleh nilai $\mathrm{t}$ hitung sebesar $0,79<\mathrm{t}$ tabel sebesar 1,97 dengan nilai signifikansi 0,43 yang berarti nilai tersebut lebih besar dari tingkat nilai 
signifikansi yang digunakan sebesar 0,05. Hal tersebut menunjukkan bahwa Net Profit Margin tidak berpengaruh signifikan terhadap pertumbuhan laba.

Hasil penelitian ini sama dengan hasil penelitian yang dilakukan oleh Kharisma Aulia Dianitha, Endang Masitoh, dan Purnama Siddi (2020) yang menunjukkan bahwa Net Profit Margin tidak berpengaruh terhadap pertumbuhan laba. Artinya jika Net Profit Margin mengalami kenaikan, maka pertumbuhan laba tidak mengalami kenaikan. Namun, hasil penelitian ini tidak mendukung penelitian yang dilakukan oleh Ulfinabella Risnawati Aryanto, Kartika Hendra Titisari, Siti Nurlaela (2018), Anggi Maharani dan Mukarim (2018), Marselia Purnama (2019) dan Suyono dan Marina (2020) yang menunjukkan bahwa Net Profit Margin mempunyai pengaruh positif terhadap pertumbuhan laba, artinya setiap kenaikan Net Profit Margin akan diikuti dengan peningkatan pertumbuhan laba. Hal ini menunjukkan bahwa Net Profit Margin mampu mempengaruhi pertumbuhan laba perusahaan karena hasil total penjualan yang tinggi dan biaya operasional perusahaan yang dapat dikendalikan dengan benar dan tepat sehingga mempengaruhi pertumbuhan laba bersih perusahaan.

\section{Pengaruh Return on Equity terhadap Pertumbuhan Laba}

Berdasarkan hasil penelitian yang telah dilakukan, diperoleh nilai $\mathrm{t}$ hitung sebesar -0,18<t tabel sebesar 1,97 dengan nilai signifikansi 0,86 yang berarti nilai tersebut lebih besar dari tingkat nilai signifikansi yang digunakan sebesar 0,05. Hal tersebut menunjukkan bahwa Return on Equity tidak berpengaruh signifikan terhadap pertumbuhan laba.
Hasil penelitian ini tidak mendukung penelitian yang dilakukan oleh Ulfinabella Risnawati Aryanto, Kartika Hendra Titisari, Siti Nurlaela (2018), Anggi Maharani dan Mukarim (2018) yang menyatakan bahwa Return on Equity berpengaruh signifikan terhadap pertumbuhan laba. Hal ini disebabkan oleh sifat dan pola investasi yang dilakukan oleh pihak perusahaan tidak tepat sehingga seluruh aktiva tidak digunakan secara efisien maka laba yang diperoleh tidak maksimal. Selain itu, modal yang dimiliki pun digunakan untuk menutupi hutang yang dimiliki. (Soehardi \& Untari, 2020).

\section{KESIMPULAN}

Berdasarkan hasil penelitian yang telah dilakukan, dapat disimpulkan bahwa :

1. Secara parsial current ratio berpengaruh signifikan terhadap pertumbuhan laba Perusahaan Sub Sektor F\&B yang terdaftar di BEI periode tahun 2010 - 2019 .

2. Secara parsial quick ratio tidak berpengaruh signifikan terhadap pertumbuhan laba Perusahaan Sub Sektor F\&B yang terdaftar di BEI periode tahun 2010 - 2019 .

3. Secara parsial debt to equity ratio berpengaruh signifikan terhadap pertumbuhan laba Perusahaan Sub Sektor F\&B yang terdaftar di BEI periode tahun 2010 - 2019 .

4. Secara parsial net profit margin tidak berpengaruh signifikan terhadap pertumbuhan laba Perusahaan Sub Sektor F\&B yang terdaftar di BEI periode tahun 2010 - 2019 .

5. Secara parsial return on equity tidak berpengaruh signifikan terhadap pertumbuhan laba Perusahaan Sub Sektor F\&B yang terdaftar di BEI periode tahun $2010-2019$.

6. Secara simultan penelitian ini menunjukkan adanya pengaruh 
signifikan antara current ratio, quick ratio, debt to equity ratio, net profit margin, dan return on equity terhadap pertumbuhan laba Perusahaan Sub Sektor F\&B yang terdaftar di BEI periode tahun $2010-2019$.

\section{Saran}

Berdasarkan kesimpulan diatas, maka saran yang dapat diberikan adalah sebagai berikut :

1. Bagi calon investor yang akan melakukan investasi di suatu perusahaan hendaknya melihat terlebih dahulu kemampuan perusahaan dalam menghasilkan laba. Para investor dapat melakukan analisis terhadap rasio keuangan perusahaan sehingga dapat memberikan gambaran mengenai kondisi perusahaan sebelum mengambil keputusan investasi.

2. Bagi perusahaan yang diteliti, hendaknya lebih memperhatikan pertumbuhan laba pada perusahaan dengan melihat faktor - faktor yang diperkirakan dapat mempengaruuhi pertumbuhan laba, sehingga laba yang diperoleh maksimal.

Bagi penelitian selanjutnya, disarankan menggunakan sampel yang tidak hanya terbatas pada sub sektor tertentu. Disarankan kepada peneliti selanjutnya untuk menambah rasio keuangan yang dapat mempegaruhi pertumbuhan laba sehingga dapat memperkuat penelitian.

\section{Daftar Pustaka}

Ahmad Rodoni, H. A. (2014). Manajemen keuangan modern. Jakarta: Mitra Wacana Media.

Dewi Utari, A. P. (2014). Manajemen Keuangan : Kajian Praktek Dan
Teori Dalam Mengelola Keuangan Organisasi Perusahaan. Jakarta: Mitra Wacana Media.

Harahap, S. S. (2015). Analisis Kritis atas Laporan Keuangan. Jakarta: Raja Grafindo Persada, .

Hery. (2015). Analisis Laporan Keuangan. Yogyakarta: CAPS (Center forAcademic Publishing Service).

Kasmir. (2018). Analisis Laporan Keuangan. Jakarta: PT. RajaGrafindo Persada.

Munawir. (2010). Analisa Laporan Keuangan. Yogyakarta: Liberty.

Munawir. (2016). Analisa Laporan Keuangan. Yogyakarta : Liberty Yogyakarta.

Sartono, A. (2012). Manajemen Keuangan Teori dan Aplikasi. Yogyakarta: BPFE.

Sawir, A. (2015). Analisa Kinerja Keuangan dan Perencanaan keauangan. Jakarta: PT. Gramedia Pustaka Utama.

Soehardi, S., \& Untari, D. T. (2020). The Effect of Covid-19 Pandemic on Hotel Employees, Hotel Occopancy Rates and Hotel Tax Income in Jakarta, Indonesia. Systematic Reviews in Pharmacy, 11(12), 964972.

https://doi.org/10.31838/srp.2020. 5.138

Sudana, I. M. (2015). Manajemen Keuangan Perusahaan (kedua ed.). Jakarta: Erlangga.

Widhi, M. S. (2011). Analisis Kemampuan Rasio-Rasio Keuangan Dalam Memprediksi Perubahan Laba. Semarang: Fakultas Ekonomi Universitas Diponogoro.

Janiman. (2018). Pengaruh Debt To Asset Ratio, Price Earnings Ratio, Dan Arus Kas Operasi Terhadap Pertumbuhan Laba (Studi Kasus Pada Perusahaan Sub Sektor 
Perdagangan Besar Barang Produksi Yang Terdaftar Di Bursa Efek Indonesia Periode 2013 - 2017). Syntax Literate, Vol. 3, No. 11 November 2018, 108-119.

Kharisma Aulia Dianitha, E. M. (2020). Pengaruh Rasio Keuangan Terhadap Pertumbuhan Laba Pada Perusahaan Makanan Dan Minuman Di BEI. Berkala Akuntansi dan Keuangan Indonesia p-ISSN: 24599581; e-ISSN 2460-4496, 14-30.

Mahaputra, I. N. (2012). Pengaruh Raio Rasio Keuangan Terhadap Pertumbuhan Laba Pada Perusahaan Manufaktur Yang Terdaftar di BEI. AUDI Jurnal Akuntansi \& Bisnis, 243 - 254.

Makiwan, G. (2018). Analisis Rasio Leverage untuk Memprediksi Pertumbuhan Laba Perusahaan Manufaktur Sub Sektor Makanan dan Minuman yang Terdaftar di Bursa Efek Indonesia Periode 20112015. Hasanuddin Student Journal Vol. 2 No. (1): 189-202, Juni 2018 PISSN: 2579-7859, E-ISSN: 2579$7867,189-202$.

Marina, S. d. (2020). Analysis Of The Effect Of Financial Ratios On Profit Growth Of Mining Companies Listed On Indonesia Stock Exchange 20132017. Bilancia: Jurnal Ilmiah Akuntansi Vol. 4 No. 1, Maret 2020 e-ISSN: 2685-5607, 1-10.

Mukaram, A. M. (2018). Pengaruh ROA, ROE, dan NPM Terhadap Pertumbuhan Laba Pada Perusahaan Sektor Industri Barang Konsumsi yang Terdaftar di Bursa Efek Indonesia. Jurnal Riset Bisnis dan Investasi Vol. 4, No. 1, April 2018 ISSN 246o-8211, 25-17.

Nuryatno, O. d. (2014). Pengaruh Rasio Keuangan Terhadap Perubahan Laba Pada Perusahaan Manufaktur Yang Terdaftar di Bursa Efek
Indonesia (BEI) 2008 - 2011. 60 77.

Purnama, M. (2019). Pengaruh Qr, Der, Npm, Ito Terhadap Pertumbuhan Laba Pada Perusahaan Keramik, Porselen Dan Kaca Tahun 20082017. Goodwill Volume 1 Nomor 2 Oktober 2019 ISSN 2684-8805 (Online), 119-129.

Ulfinabella Risnawati Aryanto, K. H. (2018). Pengaruh Likuiditas, Leverage, Profitabilitas, dan Aktivitas terhadap Pertumbuhan Laba (Studi Empiris : Perusahaan Food And Beverages yang terdaftar di Bursa Efek Indonesia periode 2011-2015). Seminar Nasional IENACO - 2018 ISSN 2337-4349, 625-631.

https://www.idx.co.id/perusahaantercatat/laporan-keuangan-dantahunan/.(n.d.). Retrieved from https://www.idx.co.id/. Diakses tanggal 28 November 2020 pukul 07.30

https://www.invesnesia.com/perusahaanmakanan-dan-minuman-dibei.(n.d.). Retrieved from https://www.invesnesia.com.

Diakses tanggal 28 November 2020 pukul 10.00

https://www.idnfinancials.com//. (n.d.).

Diakses tanggal 12 Februari 2021 pukul 19.00 